\title{
SIGNIFICANCE OF JOINT FLUID URIC ACID LEVELS IN GOUT
}

\author{
BY \\ BRIAN REEVES \\ Leverhulme Research Fellow, Royal College of Surgeons of England
}

Though the presence of synovial fluid in joints has been known since the time of Paracelsus, present concepts of synovial membrane structure and the formation of synovial fluid are of relatively recent origin. Most workers now consider the articular cavities to be connective tissue spaces; the synovial fluid is tissue fluid, and the embodied mucin is the polysaccharide protein component of other connective tissue.

This hypothesis is supported by the fact that nonelectrolytes diffuse readily in either direction between blood and synovial fluid and that electrolytes are distributed in accordance with the GibbsDonnan theory of membrane equilibrium (Ropes, Bennett, and Bauer, 1939). Chloride and bicarbonate are present in higher concentration in the fluid than in the serum, while concentrations of sodium, potassium, calcium, and magnesium are lower in the fluid. The mobility of many ions in synovial tissue is the same as in water but the bivalent cations have a lower apparent mobility in tissues than in water (Joseph, Reed, Steck, Folk, and Kaplan, 1948).

Because of these facts, it has usually been assumed that the synovial fluid level of uric acid follows at a slightly lower level than that of the serum, and this assumption has been supported by the work of Ropes and Bauer (1953) and Talbott (1957), who refute the earlier observation by Kling (1938) that the level of joint fluid may be significantly raised above that of the serum in an acute attack of gout.

Observations I have made, however, support the original thesis of Kling, and suggest that this higher level of joint fluid uric acid is associated with the formation of urate crystals in the joint fluid.

\section{Material and Methods}

28 specimens of knee joint synovial fluid were examined from 27 patients, eight of whom were suffering from gout, seven from rheumatoid arthritis, six from traumatic synovitis with non-haemorrhagic effusions, and one from osteochondritis dissecans (Table, overleaf).

A blood sample was taken at the same time as aspiration of the knee joint.

Synovial fluid was examined directly under normal polarized light for crystals, and after treatment of the fluid with hyalase and trypsin and differential centrifugation to deposit the crystals (after the method of Kohn, Hughes, McCarty, and Faires, 1962) for the preparation of calcium pyrophosphate crystals. Confirmation was obtained by uricase digestion of the crystals.

Uric acid levels of synovial fluid were measured on whole fluid within a few hours of aspiration, the clot which formed in three of the rheumatoid patients (Nos 10,11 , and 14 in the Table) being discarded. Uric acid levels in both serum and synovial fluid were estimated using the differences in ultra-violet light absorption between specimens which had and had not undergone uricase digestion (Feichtmeir and Wrenn, 1955).

\section{Results}

Gout.-Of the nine gouty fluids from eight patients, crystals of urate were found in five of the seven fluids examined. Each of these patients had a high acid level (range $5 \cdot 8$ to $7 \cdot 9$ ) in the joint fluid; in only one instance (Patient 8) was the joint uric acid level lower than that in the serum. In three of the nine fluids the joint level was slightly below the serum level and in one it was equal, but in the other five it was significantly above. Crystals were looked for in four of this latter group of five and were found in the untreated fluid in all patients.

Other Diseases.-Nineteen joint fluids from patients with diseases other than gout were examined. In only one of these (Patient 13 with rheumatoid arthritis) was the joint fluid uric acid level very slightly greater than the serum level, while in four cases $(11,19,20,27)$ the levels were the same. Urate crystals were not found in any of fourteen fluids in which they were sought. 
TABLE

Findings in 27 Patients

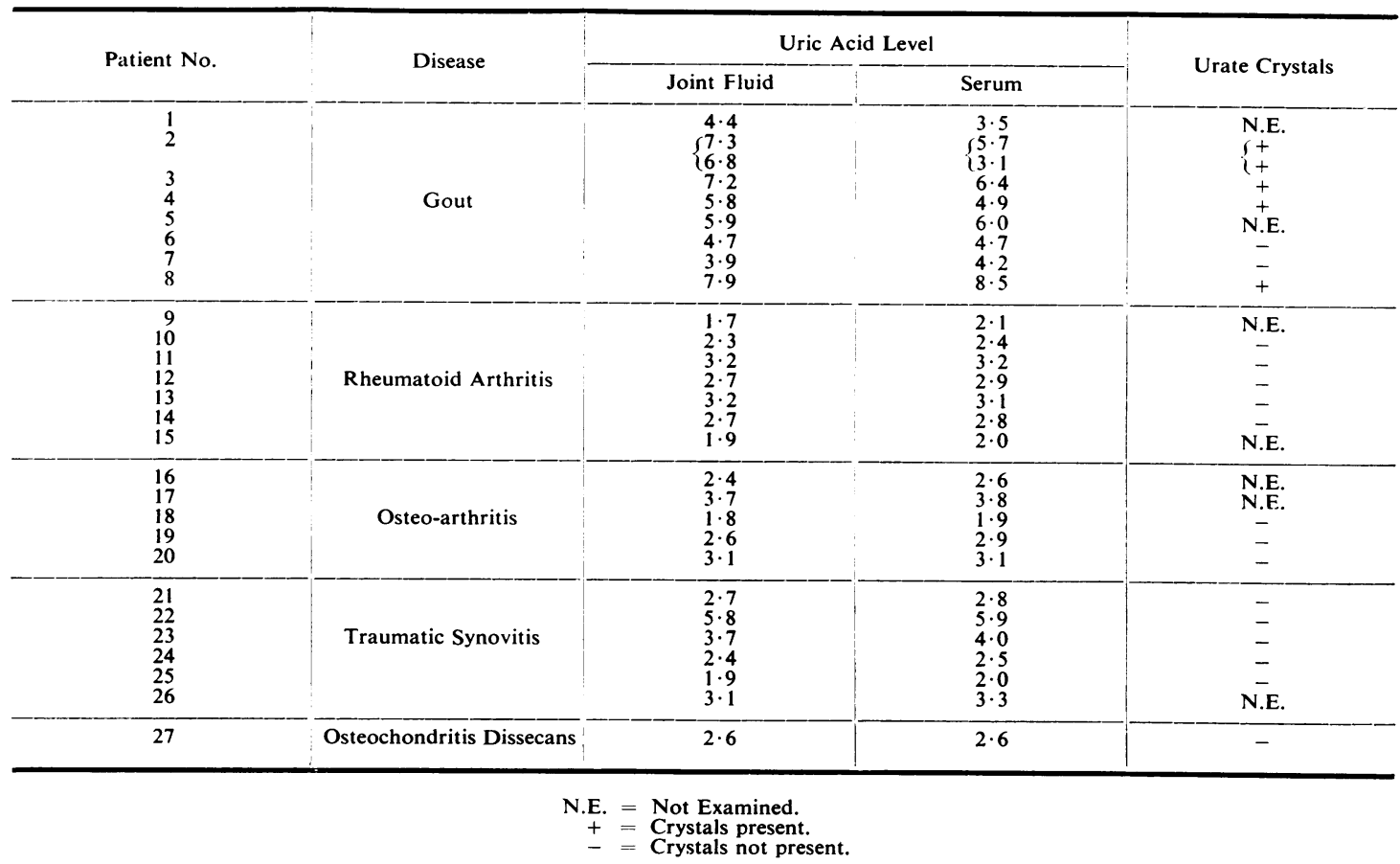

\section{Conclusion}

Crystals of urate were discovered in four out of six patients with gouty effusion of the knee; though this does not compare with the identification of crystals in effusion from 21 out of 22 patients by Zvaifler and Pekin (1963), it does represent a much greater incidence that had been previously believed to occur.

In all the joint fluids with a high uric acid level crystals were found and it is possible that their presence explains the higher uric acid level in the joint than in the serum. Why this occurs is, however, still a matter for speculation.

The results shown in the Table suggest that the joint fluid uric acid level is a better solitary diagnostic factor than the serum uric acid level, and furthermore that a joint uric acid level significantly above the serum uric acid level is diagnostic of gout, as was originally suggested by Kling (1938) but later denied by Ropes and Bauer (1953).

\section{Summary}

28 knee joint synovial fluids were examined for urate crystals and the uric acid levels in joint fluid and serum were estimated. The joint uric acid level was significantly greater than the serum uric acid level in four of the eight patients with gout. In three of these patients with higher joint uric acid levels and in one other gouty patient, urate crystals were seen in the joint fluid.

My thanks are due to Mr. R. H. Young, who originally suggested this project, and to the staff of the Orthopaedic Department of St. George's Hospital, S.W.1., who kindly allowed me to investigate their patients.

\section{REFERENCES}

Feichtmeir, T. V., and Wrenn, H. T. (1955). Amer. J. clin. Path., 25, 833.

Joseph, N. R., Reed, C. I., Steck, I. E., Folk, F., and Kaplan, E. (1948). Amer. J. Physiol., 153, 364.

Kling, D. H. (1938). "The Synovial Membrane and the Synovial Fluid", p. 210. Medical Press, Los Angeles.

Kohn, N. N., Hughes, R. E., McCarty, D. J., and Faires, J. S. (1962). Ann. intern. Med., 56, 738.

Paracelsus Quoted by Hyrtl, J. (1880). "Onomatologia Anatomica." Braumüller, Vienna. 
Ropes, M. W., and Bauer, W. I. (1953). " "Synovial Fluid Changes in Joint Disease", pp. 64-65. Harvard University Press, Cambridge, Mass.

, Bennett, S. A., and Bauer, W. (1939). J. clin. Invest., 18, 351.

Talbott, J. H. (1957). "Gout", p. 40. Grune and Stratton, New York.

Zvaifler, N. J., and Pekin, T. J. (1963). Arch. intern. Med., 111, 99.

L'importance des taux de l'acide urique dans le liquide synovial des goutteux

RÉSUMÉ

On a examiné le liquide synovial de 28 genoux; on y a recherché les cristaux d'urate et on a déterminé le taux d'acide urique dans ce liquide et dans le sérum. Ce taux était significativement plus grand dans le liquide articulaire que dans le sang chez quatre sur huit malades goutteux. Chez trois malades aux taux de l'acide urique synovial élevé et chez un autre goutteux on a trouvé des cristaux d'urate dans le liquide synovial.

La importancia de las cifras del ácido úrico en el líquido sinovial de los gotosos

\section{SUMARIO}

El líquido sinovial de 28 rodillas fué examinado; se buscaron cristales de urato y se determinaron las cifras del ácido úrico en este líquido y en el suero. Estas cifras fueron significativamente mayores en el líquido articular que en la sangre en cuatro de ocho enfermos con gota. En tres enfermos con el ácido úrico sinovial aumentado y en un otro gotoso se encontraron cristales de urato en el líquido sinovial. 